\title{
Effect of drying, freezing and storage of dried and frozen onion (Allium cepa L.) on its pungency
}

\author{
MARCIN HORBOWICZ, JÓZEF BĄKOWSKI \\ Research Institute of Vegetable Crops, Department of Storage and Processing, \\ Konstytucji 3 Maja 1/3, 96-100 Skierniewice, Poland
}

(Receive: December, 4. 1997)

A bstract

\begin{abstract}
The paper contains results of studies of drying and freezing effects, as well as storage of dried and frozen onion on its pungency. The effect of onion bulbs preparation on pungency was estimated as well. The pungency measurements were based on determination of pyruvate produced enzymatically by alliinase. Storage at $20^{\circ} \mathrm{C}$ of skinned onion decreases sligthly pungency, however three weeks storage at $0-2^{\circ} \mathrm{C}$ did not change it. Other results indicate that freezing at $-25^{\circ} \mathrm{C}$, and followed thawing led to large losses - reaching $75 \%$ of pungency found in the onion taken to the process. Storage of the frozen onion caused further decrease its pungency. Decrease of pungency during drying was depended on temperature of the process. Low drying temperature $\left(40\right.$ and $50^{\circ} \mathrm{C}, 20$ hours) caused only $15-20 \%$ decline of pungency. Higher temperature drying $\left(60^{\circ} \mathrm{C}\right)$ resulted in $50 \%$ losses of onion pungency.
\end{abstract}

\section{INTRODUCTION}

The main function of onion as a dietary component depends upon its characteristic flavor. Traditionally onions have been consumed raw as salad and after processing as the dried or pickled vegetable. Dehydrated onion is used widely in sauces, soups, mayonnaise, salad dressing and other products. Recently a chopped and frozen onion was introduced to market as flavor component for use in salad bars and restaurants. It seems from practical point of view that frozen onion is more convinient than raw for such purposes.

Intact Allium cells have no odor, but when they are disrupted the enzyme alliinase hydrolyzes some sulfur amino acids to produce pyruvate, ammonia and the many volatile sulfur compounds associated with flavor. Onion flavor can be determined by measurements of flavor precursors, reaction products, or alliinase activity ( $\mathrm{L} \mathrm{a} \mathrm{n} \mathrm{c} \mathrm{a-}$ s te r and B ol and, 1990). Pyruvate analysis is most common and useful method of Allium pungency estimation. It measures total pungency (amounts of all cysteine sul- 
foxides hydrolyzed by alliinase), and does not estimate relative amounts of individual precursors or final flavor volatiles. The technique was found highly $(\mathrm{r}=0.97)$ correlated with threshold concentration of onion juice detected by smell ( $\mathrm{S} \mathrm{ch} \mathrm{w} \mathrm{i} \mathrm{m} \mathrm{me} \mathrm{r}$ and $\mathrm{G} u$ a d a $\mathrm{g} \mathrm{n} \mathrm{i,1962).} \mathrm{Tasting} \mathrm{technique} \mathrm{of} \mathrm{individual} \mathrm{onion} \mathrm{bulbs} \mathrm{is} \mathrm{highly} \mathrm{corre-}$ lated with pyruvate level as well (Wa 11 and Corg a n, 1992). Pyruvate analysis as a method of onion pungency estimation was introduced by $\mathrm{S} \mathrm{chwimmer}$ and Weston (1961). Because of the mentioned correlations, and simplicity of procedure the method is widely used ( $\mathrm{R}$ and le, 1992; R a nd le and B u s s a rd, 1993; Yo o et al., 1995).

Pyruvic acid is produced by alliinase hydrolysis of S-alk(en)yl-L-cysteine sulfoxides in Allium tissues when they are mechanically chopped or macerated:

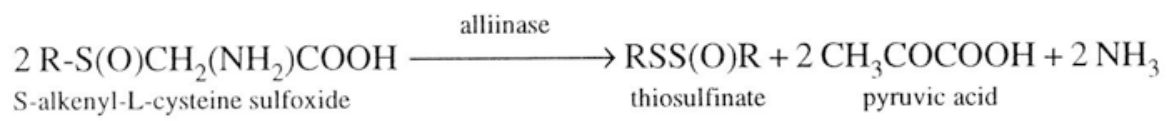

In case of onion $\mathrm{R}$ means methyl, propyl or 1-propenyl (C a r s o n and Wo $\mathrm{ng}$, 1961, L a n c a s ter and B o l a n d, 1990). The last one sulfoxide, commonly called allin or S-allyl cysteine, is major precursor of onion flavor. Besides pyruvate and ammonia among the reaction products are the many sulfur compounds characteristic of onion flavor and aroma. Tiosulfinates are quite unstable compounds, and after series of reactions are converted into tiosulfonates, sulfides, disulfides, and thiopropanal S-oxide too.

There are some discrepancies among published results according effect of drying and freezing on pungency of onion. Fr e e m a n and W he n h a m (1974) have stated that commercially frozen onion lost all its pungency, and in laboratory frozen onion losses were equal $54 \%$. Results of the same paper have shown that decreases of pungency during semi-technical drying $\left(70^{\circ} \mathrm{C}\right.$ - initially, and then during 7 hours at $50^{\circ} \mathrm{C}$ ) were ranged from 73 to almost $96 \%$, depends on cultivar. According to $\mathrm{K} \mathrm{a} \mathrm{a} \mathrm{c} \mathrm{k}$ (1988) losses of pungency during onion freezing reached only $30 \%$, and further decline occurred during storage at $-25^{\circ} \mathrm{C}$. The decline of pungency during onion freezing is probably caused by deactivation of alliinase activity (Fre e m a n and

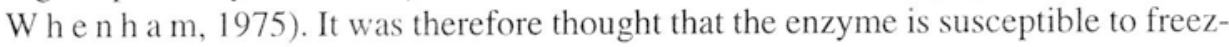
ing. However results published by Wä fle $\mathrm{r}$ et al. (1994) show that purified alliinase can be stored at $-80^{\circ} \mathrm{C}$ without any loss of activity. The enzyme also remains active after quick freezing of fresh onion tissue in liquid nitrogen.

The main aims of presented paper were to check what size of pungency losses are during preparing for processing, semi-technical drying and freezing, and during storage of frozen and dried several cultivars onion produced in Poland.

\section{MATERIALS AND METHODS}

\section{Preparation of onion for processing}

In first experiment dry outer skin was handly removed from onion bulbs (cv. Hyduro), and then such bulbs were stored at $0-2^{\circ} \mathrm{C}$ or $20^{\circ} \mathrm{C}$. Pungency was analyzed before, and after 3,7 or 21 days of storage. 
In second experiment onion (cv. Hyduro) was sliced onto $5 \mathrm{~mm}$ thick rings, and pungency was measured after dipping cut onion for 10 or 30 minutes in tap water.

\section{Onion dehydration}

Dehydrated onion (cv. Sochaczewska) was obtained from an experimental semitechnical fan dryier. Skinned onion bulbs were cut into $5 \mathrm{~mm}$ rings in semi-technical slicer, and then transferred to perforated trays and dried. Initial temperature of hot air was $60^{\circ} \mathrm{C}$, and after 2 hours of drying was decreased to $40^{\circ} \mathrm{C}$. The total drying time was 8 hours. Dried onion rings was stored in dark at room temperature in twist capped glass jars. Part of dried onion was pulverized in laboratory mill, and stored in the same conditions.

In another experiment onion (cv. Sochaczewska) has been dried during 20 hours at 40,50 or $60^{\circ} \mathrm{C}$, and then was stored without pulverizing as described above.

\section{Onion freezing}

Freezing of onion (cv. Sochaczewska) was done after cutting bulbs into $5 \mathrm{~mm}$ rings. It was done handly. Sliced onion was frozen in thin layers on aluminum trays at $-25^{\circ} \mathrm{C}$, and after packing in polyethylene bags stored at $-25^{\circ} \mathrm{C}$.

In second experiment onion was cut onto $1.5 \mathrm{~cm}$ cubes or $3 \mathrm{~mm}$ rings using technical slicer. To the experiment six cultivars was taken, and pungency has been estimated in fresh (hand cutting), and next day after freezing at $-25^{\circ} \mathrm{C}$, and thawing at room temperature during half hour.

\section{Estimation of pungency. Extraction of pyruvate}

The pungency determination was carried out by the S chwim mer and We s t o n (1961) method based on enzymatic synthesis of pyruvate, with some modifications. About twenty bulbs were taken to pungency analyses of fresh onion tissue. Each of bulb was cut half equatorially and a $0.5-1.0 \mathrm{~cm}$ ring was taken to pungency analyzes. The rings were hand cut on small cubes, mixed, and immediately analyzed. One $10 \mathrm{~g}$ portion of such sample was boiled during 5 minutes in $50 \mathrm{ml}$ of distilled water for alliinase inactivation. This sample was prepared for determination of background pyruvate level. Three another 10-grams portions were homogenized in $50 \mathrm{ml}$ of water using Waring blendor, and left for one hour in room temperature to end of enzymatic biosyntehsis of pyruvate. After one hour the slurry transferred to $100 \mathrm{ml}$ volumetric flask and filled to the mark with water. To spectrophotometric analysis from each sample a $0.1 \mathrm{ml}$ of filtered solution was taken.

Frozen onion was analyzed on similar way, with the exception that 25 grams was taken for inactivation of alliinase (background pyruvic acid), and three another 25 grams portions were homogenized, and after homogenization and filtration the total volume was $250 \mathrm{ml}$.

In case of dried material a $2 \mathrm{~g}$ samples were homogenized with $50 \mathrm{ml}$ of water using Ultra-Turrax blendor, and left at room temperature for 3 hours, to full rehydration and finish of enzymatic process. Another sample in $50 \mathrm{ml}$ of water was bolied 
during 5 minutes (alliinase inactivation). Then the samples were diluted to $100 \mathrm{ml}$ volume. Rest of procedure was similar to analyses pungency of fresh tissue.

\section{Spectrophotometric procedure}

One hundred microliters of solution was transferred to polypropylene $7 \mathrm{ml}$ vial, $1.9 \mathrm{ml}$ distilled water was added, then $1 \mathrm{ml}$ of $0.1 \%$ of dinitro-phenylhydrazine (DNPH) in $2 \mathrm{~N} \mathrm{HCl}$, and after shaking the mixture was left on 15 minutes in dark. Afterward $3 \mathrm{ml}$ of $1.25 \mathrm{~N} \mathrm{NaOH}$ was added, mixed, and incubated for 0.5 hour at room tempearture. Absorbance was measured with Bausch \& Lomb colorimeter set at 440 nm. As a blank sample water plus DNPH and $\mathrm{NaOH}$ solutions were taken. Calibration curve (range: $2-40 \mathrm{mg} / \mathrm{sample}$ ) was prepared weekly, or after preparing of new reagents. Final pyruvate concentration in micromoles per gram of fresh weight was calculated from the difference between pyruvate levels in the samples and inactivated control (background pyruvate).

The results were statistically elaborated using computer analysis of variance, $\mathrm{t}$-Student test was used for LSD calculation (results in tables), and standard deviation values were calculated and shown on figures.

\section{RESULTS AND DISCUSSION}

During preparation of onion bulbs for processing losses of pungency were relatively low (Table 1 and 2). Decline of pungency in skinned bulbs was not found during storage at low temperature $\left(0-2^{\circ} \mathrm{C}\right)$. However storage at room temperature (about $20^{\circ} \mathrm{C}$ ) caused $20 \%$ decrease of skinned onion pungency (Table 1). Longer (30 minutes) dipping sliced onion in water resulted in $15 \%$ decrease of its pungency. Dipping is sometimes use before drying of onion, to protect onion from browning reactions. Dipping removes monosugars from surface layer of onion, and therefore decrease Maillard reactions. It seems that at the same time dipping partly removes precursors responsible for biosynthesis of onion pungency.

Among analyzed cultivars Summit, Armstrong and Supra had highest level of pungency: 11.7, 10.4 and 10.2 $\mu \mathrm{Mol}$ of pyruvic acid (PA) in one gram of fresh onion

Table 1 - Tabela 1

Effect of storage conditions on onion pungency (cv. Hyduro) after removing dry, outer scale (PA - pyruvic acid; LSD - least significant difference; ns - non-significant differences)

\begin{tabular}{|l|c|c|}
\hline \multirow{2}{*}{ Analyzed tissue } & \multicolumn{2}{|c|}{ Onion pungency $(\mu \mathrm{Mol}$ PA/g of fresh weight) } \\
\cline { 2 - 3 } & storage at $0-2^{\circ} \mathrm{C}$ & storage at $20^{\circ} \mathrm{C}$ \\
\hline fresh onion, after remove of outer dry scale & 8.4 & $8.4 \mathrm{a}$ \\
after 3 days storage without dry scale & - & $7.7 \mathrm{ab}$ \\
after 7 days storage without dry scale & 7.5 & $6.7 \mathrm{~b}$ \\
after 21 days storage without dry scale & 8.3 & - \\
\hline LSD, a=0.05 & $\mathrm{ns}$ & 1.2 \\
\hline
\end{tabular}


Table 2 - Tabela 2

Pungency of onion (cv.Hyduro) after dipping in water

(PA - pyruvic acid; LSD - least significant difference).

\begin{tabular}{|l|c|}
\hline Analyzed onion & $\begin{array}{c}\text { Pungency } \\
(\mu \mathrm{Mol} \text { PA/g tissue })\end{array}$ \\
\hline Fresh, $0.5 \mathrm{~cm}$ thick, onion rings & $8.4 \mathrm{a}$ \\
Onion rings dipped for 10 minutes in water $(2 \mathrm{~kg}$ of onion $+4 \mathrm{~kg}$ of tap water $)$ & $9.1 \mathrm{a}$ \\
Onion rings dipped for 30 minutes in water $(2 \mathrm{~kg}$ of onion $+4 \mathrm{~kg}$ of tap water $)$ & $7.2 \mathrm{~b}$ \\
\hline LSD, a=0.05 & 1.1 \\
\hline
\end{tabular}

tissue respectively (Table 3). Smaller pungency occured in three other cultivars: Dawidowska, Robusta and Hyduro: 9.4, 9.4 and $8.5 \mu \mathrm{Mol}$ PA/g FW respectively. The all analyzed cultivars belong to intermediate pungent onion, according to rank scale proposed by Schwimmer and Weston (1961). Sochaczewska cultivar used to drying and freezing processes had 8.8-11.0 $\mu \mathrm{Mol} \mathrm{PA} / \mathrm{g} \mathrm{FW}$, depend on year and place of its production.

Freezing of onion caused large losses of pungency (Table 3). Depends on studied cultivar and kind of material subjected to freezing only 31.6 to $46.8 \%$ of pungency in onion tissue retain after freezing at $-25^{\circ} \mathrm{C}$, and thawing on the next day. Freezing of onion rings slightly reduce the pungence losses, compare to freezing onion as a $1.5 \mathrm{~cm}$ cubes. Th results of pungency decline after freezing process presented here are similar to those published by Fre e $\mathrm{m}$ a $\mathrm{n}$ and $\mathrm{W}$ h e $\mathrm{n} \mathrm{h}$ a m (1974). Those authors have found $53.6 \%$ losses of pungency during laboratory freezing of onion (cv. R i j n s bu r g e r). For comparison they stated that commercially frozen onion of the same cultivar had no pungency at all. It seems that conditions of freezing (temperature, and time) are most important step for pungency retention. According to Wäfler et al. (1994) onion retains nearly all its pungency (measured as alliinase activity) after quick freezing in liquid nitrogen. Slow freezing at $-20^{\circ} \mathrm{C}$ and $1.5 \mathrm{~h}$ thawing time caused almost all alliinase deactivation. It is likely, that freezing could

$$
\text { Table } 3 \text { - Tabela } 3
$$

Changes of onion pungency after freezing of different cultivars cut into $1.5 \mathrm{~cm}$ cubes and $0.5 \mathrm{~cm}$ thick rings (PA - pyruvic acid; FW - fresh weight tissue; LSD - least significant difference)

\begin{tabular}{|c|c|c|c|c|c|}
\hline \multirow[t]{2}{*}{$\begin{array}{l}\text { Name of analyzed } \\
\text { cultivar }\end{array}$} & \multirow{2}{*}{$\begin{array}{c}\text { Pungency of } \\
\text { fresh onion } \\
\mu \mathrm{Mol} \text { PA /g FW }\end{array}$} & \multicolumn{2}{|c|}{$\begin{array}{l}\text { Pungency of frozen onion } \\
\text { cubes }\end{array}$} & \multicolumn{2}{|c|}{$\begin{array}{l}\text { Pungency of frozen } \\
\text { onion rings }\end{array}$} \\
\hline & & $\mu \mathrm{Mol} / \mathrm{g}$ & $\%$ of fresh & $\mu \mathrm{Mol} / \mathrm{g}$ & $\%$ of fresh \\
\hline Dawidowska & $9.4 \mathrm{bc}$ & $3.4 \mathrm{bc}$ & 36.1 & $3.3 \mathrm{~b}$ & 35.1 \\
\hline Summit & $11.7 \mathrm{a}$ & $3.7 \mathrm{ab}$ & 31.6 & $3.5 \mathrm{~b}$ & 29.9 \\
\hline Armstrong & $10.4 \mathrm{ab}$ & $4.2 \mathrm{a}$ & 40.4 & $4.2 \mathrm{a}$ & 40.4 \\
\hline Supra & $10.2 \mathrm{ab}$ & $3.6 \mathrm{ab}$ & 35.3 & $4.3 \mathrm{a}$ & 42.2 \\
\hline Hyduro & $8.5 \mathrm{c}$ & $2.8 \mathrm{c}$ & 32.9 & $3.1 \mathrm{~b}$ & 36.5 \\
\hline Robusta & $9.4 \mathrm{bc}$ & $3.2 \mathrm{bc}$ & 34.0 & $4.4 \mathrm{a}$ & 46.8 \\
\hline mean & - & - & 35.1 & - & 38.5 \\
\hline LSD, $a=0.05$ & 1.5 & 0.7 & - & 0.5 & - \\
\hline
\end{tabular}


induce conformatinal changes of alliinase protein, leading to loss of enzyme activity (Wä f l e r et al.,1994). On the other hand Fr e e m a n and W h e $n$ h a m (1974) have suggested that during processing (freezing or drying) non-enzymic destruction of flavot precursor can occur.

In another experiment during freezing of cut onion (cv. Sochaczewska) almost $73 \%$ of its pungency was lost (Fig. 1). After first month of storage of frozen onion the pungency further declined to below of $10 \%$ the level observed in fresh tissue. Longer storage ( 3,5 and 7 months) caused gradual, although non-significant decrease of the pungency level. After 7 months of storage frozen onion lost about $95 \%$ of fresh onion pungency.

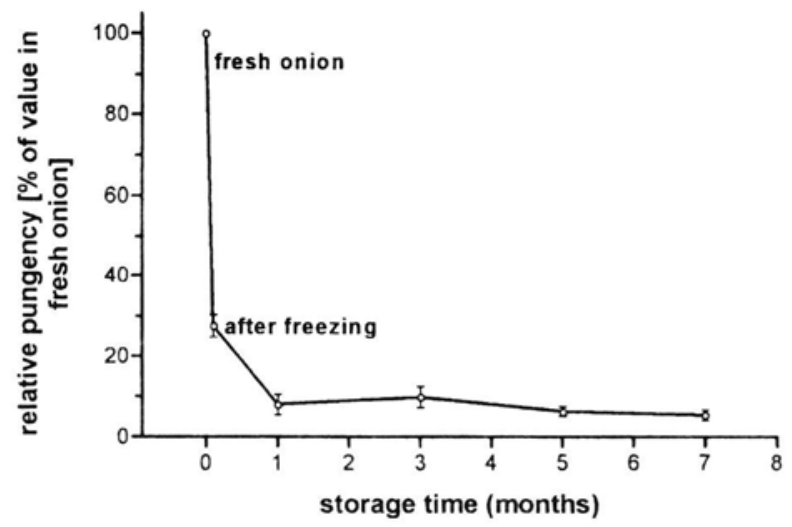

Fig. 1. Changes of relative pungency during freezing and storage at $-25^{\circ} \mathrm{C}$ of onion (cv. Sochaczewska, mean of three replicates \pm standard deviation).

The results of pungency determination of dried onion are presented on figures 2 and 3. During drying of sliced onion initially for 2 hours at $60^{\circ} \mathrm{C}$, and afterwards at $40^{\circ} \mathrm{C}$ during six hours, pungency was decreased almost 50\% (Fig.2). After seven months storage of dried onion rings the pungency was only slightly lower from that after drying. Larger decline of pungency occured after 3 and 7 months storage of powdered, dried onion. Figure 3 contains results of study on effect of drying temperature, and further storage on pungency of dried onion rings. It is clear from these data that temperature used for drying process is crucial for retaining of onion pungency. Drying at temperature $60^{\circ} \mathrm{C}$ for 20 hours decreased level of PA more then $50 \%$. During the same time at temperature $40^{\circ} \mathrm{C}$ and $50^{\circ} \mathrm{C}$ the decreases were equal $15 \%$ and about $20 \%$ respectively. After one month of storage further declines of PA levels were noted, but they were relatively small. Thus after five months of storage onion dried at $40^{\circ} \mathrm{C}$ had $79 \%$ of initial pungency value found in raw, dried at $50^{\circ} \mathrm{C}$ had $70 \%$, and at $60^{\circ} \mathrm{C}$ had $41 \%$ of raw onion pungency. The results on effect of drying on pungency retention in dried onion presented here, are much higher than those published by Freeman and Wh e n h a m (1974). During semi-technical drying of nine cultivars of on- 
ion they have found 78 to $96 \%$ losses of alliinase obtained pyruvate. One explanation of those discrepancies is drying conditons. Drying process of onion carried out by mentioned authors was started at $70^{\circ} \mathrm{C}$, and then temperature was slowly decreased to $50^{\circ} \mathrm{C}$. Total drying time was 5-6 hours. It is likely the high temperature on opening of drying process could destroy most of alliinase, or flavor precursors. As was shown on figure 2 , use $60^{\circ} \mathrm{C}$ as an initial temperature of drying process, caused $50 \%$ decrease of product pungency.

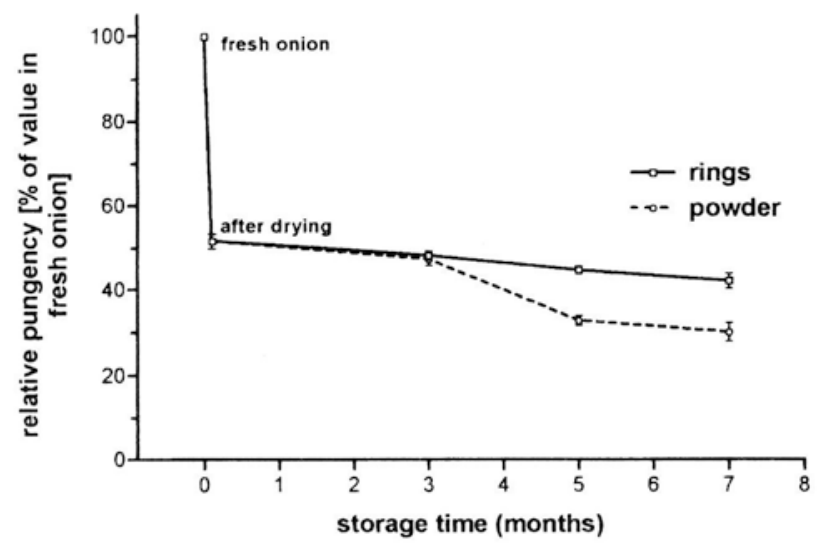

Fig. 2. Changes of relative pungency during drying and storage of dried rings and powder of onion (cv. Sochaczewska, mean of three replicates \pm standard deviation).

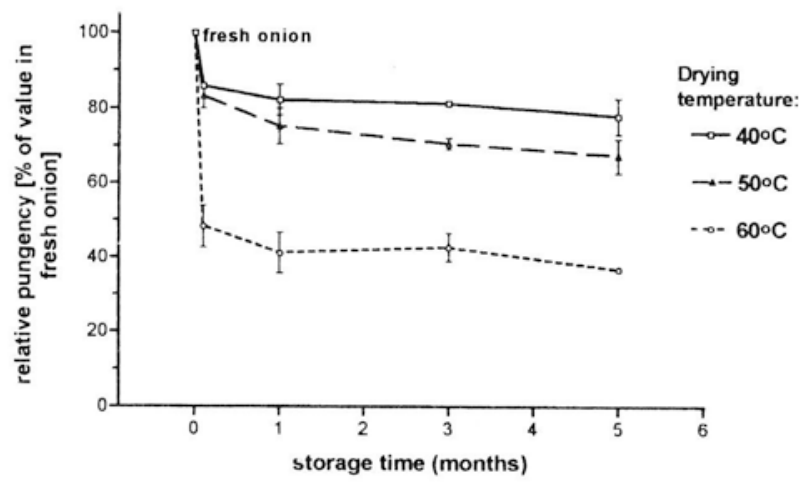

Fig. 3. Effect of drying temperature and storage time on relative pungency of dried onion (cv. Sochaczewska, mean of three replicates \pm standard deviation).

\section{CONCLUSIONS}

1. Removing of dry onion skin, and store skinned bulbs at $20^{\circ} \mathrm{C}$ lowered of pungency level. Three weeks storage of skinned onion at $0-2^{\circ} \mathrm{C}$ retains all its pungency. 
2. Retention of pungency after slow freezing process at $-25^{\circ} \mathrm{C}$ was very low ranged from $31.6 \%$ to $46.8 \%$ of initial level noted at raw onion.

3. Storage of frozen onion during 7 months caused further decrease of pungency reached $95 \%$ of initial value found in fresh onion taken for freezing.

4. Losses of pungency during drying depend on temperature of the process. Drying at $40^{\circ} \mathrm{C}$ or $50^{\circ} \mathrm{C}$ caused much smaller decrease of enzymatically produced pyruvic acid, than drying at $60^{\circ} \mathrm{C}$.

\section{REFERENCES}

Cars on J. F., Wong F. F, 1961. The volatile flavor components of onions. J.Agr.Food Chem. 9: 140-142

Fre e m a n G. G., Wh e $\mathrm{n} \mathrm{ham} \mathrm{R.} \mathrm{J.,} \mathrm{1974.} \mathrm{Changes} \mathrm{in} \mathrm{onion} \mathrm{(Allium} \mathrm{cepa} \mathrm{L.)} \mathrm{flavour} \mathrm{components} \mathrm{resulting}$ from some post-harves processes. J.Sci.Fd.Agric. 25: 499-515

Fre e m an G. G., Wh he $\mathrm{h}$ a m R. J., 1975. The use of synthetic ( \pm )-S-propyl-L-cysteine sulphoxide and of alliinase preparations in studies of flavour changes resulting from processing of onion (Allium cepa $\mathrm{L}$.). J.Sci.Fd.Agric. 26: 1333-1346

K a a ck K., 1988. Changes in pyruvic acid formation capacity in frozen onion. Tidsskrift for Planteavl. 92: 275-278

Lancaster J. E., B oland M. J., 1990. Flavor biochemistry, p.33-72. In: H. D. Rabinowitch and J. L. Brewster (eds.). Onion and allied crops, vol.III, CRC Press, Boca Raton, FL, USA

$\mathrm{R}$ and le W. M.. 1992. Sampling procedures to estimate flavor potential in onion. HortScience 27: 1116-1117

R andle W. M., B uss ard M. L., 1993. Streamling onion pungency analyses. HortScience 28: 60

S chw i m me r S., Guadag n i D. G., 1962. Relation between olfactory threshold concentration and pyruvic acid content of onion juice. J.Food Sci. 27: 94-97

S chwimmer S., Weston W. J. 1961. Enzymatic development of pyruvic acid in onion as a measure of pungency. J. Agr Food Chem. 9: 301-304

Wall M. M., Corgan J. N., 1992. Relationship between pyruvate analysis and flavor perception for onion pungency determination. HortScience 27: 1029-1030.

Wäfler U., Shaw M. L., Lancaster J. E., 1994. Effect of freezing upon alliinase activity in onion extracts and pure enzyme preparations. J.Sci.Fd. Agric. 64: 315-318

Yoo K. S., Pike L. M., Hamilton B. K., 1995. A simplified pyruvic acid analysis suitable for onion breeding programs. HortScience 30: 1306

\section{Wpływ suszenia, mrożenia oraz przechowywania suszów i mrożonek na „ostrości” cebuli (Allium cepa L.)}

\section{Streszczenie}

PREZENTOWANA PRACA ZAWIERA wyniki badań dotyczących wpływu suszenia i mrożenia, oraz przechywania suszów i mrożonek na „ostrość” cebuli. Zbadano też wpływ wstępnego przygotowania cebuli na jej „ostrość”. Oznaczanie „ostrości” przeprowadzono poprzez analizę zawartości kwasu pirogronowego jako produktu działania enzymu -allinazy. Przechowywanie obranej cebuli w $20^{\circ} \mathrm{C}$ w niewielkim stopniu obniżało jej „ostrość”, zaś trzytygodniowe przechowanie w temperaturze $0-2^{\circ} \mathrm{C}$ nie zmieniło „ostrości”. Inne rezultaty wskazują. że mrożenie cebuli i następne jej rozmrażanie prowadzi do dużych strat „ostrości” - osiągających 75\% wyjściowych wartości w cebuli użytej do tego procesu. Przechowywanie mrozonej cebuli prowadziło do dalszych ubytków „ostrości”. Straty „ostrości” podczas suszenia cebuli były zależne od zastosowanej temperatury tego procesu. Niska temperatura suszenia (40 lub $50^{\circ} \mathrm{C}, 20$ godzin) powodowała $15-20 \%$ ubytki „ostrości”. W wyniku zastosowania wyższej temperatury suszenia $\left(60^{\circ} \mathrm{C}\right)$ straty sięgały $50 \%$. 